\title{
サブナノメータの分解能を持つ 反射光電式変位計の試作*
}

\author{
井川直哉**島田尚 一** 師岡英 行**
}

Development of Reflective Photoelectronic Displacement Sensor with Subnanometer Resolution

Naoya Ikawa, Shoichi Shimada and Hideyuki Morooka

\begin{abstract}
The design of an ultraprecision displacement sensor with subnanometer resolution is proposed for the use of ultraprecision technologies. The principle of the sensor is based on the high-sensitive detection of power change at a specific point in the light reflected from the object surface which is subject to a small displacement. The sensor consists of the single light source, the reflective object and reference surfaces, the optical fiber bundles for transmission of the illuminating and the reflected light and the photodiodes setup. In operation, the object and the reference surfaces are illuminated by the light transmitted through the optical fiber bundles from the single light source. Then, the reflected light from both surfaces are transmitted through the other optical fiber bundles to two separated but equivalent photodiodes respectively. By using the differential amplifier, the diodes enable to give a high-sensitive displacement signal which is included in the total signal of the reflected light. The sensor proposed here has some distinctive features such as the non-contact measurement, the high resolution of $0.5 \mathrm{~nm}$, the wide working range of about $30 \mu \mathrm{m}$ within the $5 \%$ linearity and the sufficient stability of $1 \mathrm{~nm}$ in 20 seconds for specific research purposes.
\end{abstract}

Key words : optical measurement, photoelectronic displacement sensor, non-contact measurement, nanometer resolution

\section{1. 緒言}

2 物体間の微小变位を高精度にしかも非接触で測定 寸る技術は寸法や変形量の評価あるいは位置決めを必 要と寸るあらゆる分野において要求される極めて重要 な技術である。このよらな目的のために一般に用いら れている非接触变位計には静電容量式, 高周波渦損式, 光電式等の種々の形式のものがあるが, 現在のところ, その分解能はいずれも最高のもので $20 \mathrm{~nm}$ 程度であ る。一方, 最近は, いわゆる超精密加工によって, 形 状精度 $100 \mathrm{~nm}$, 表面粗さ $10 \mathrm{~nm}$ 台の加工が多くの光 学部品や電子部品で多用される傾向にあるが, 加工精 度の評価, 精度要因の解析を, それらょりも 1 けた高 い精度で行う必要性が工作機械や計測機器の分野で急 増してきた。

本研究は，それらの要求にこたえることのできる，

* 原稿受付 昭和 61 年 6 月 13 日. 昭和 59 年度精機学会春季 大会学術講演会 (昭和 59 年 3 月 27 日) にて発表

** 正会 員 大阪大学工学部 (吹田市山田丘 2-1) $\mathrm{nm}$ レベルの分解能を持った非接触変位計の開発を目 的としたもので，その基本原理は被測定面に照射した 光のある位置での反射光量が，物性值としての表面反 射率, 表面粗さおよび面の変位によって変化するとい ら現象を利用するものである。この基本原理およびそ の測定への応用例は既にいくつか報告されている，例 えば斎藤らは表面粗さを評価する光沢計としてこの原 理を利用している1)が，この場合は変位に対する感度 が極めて低いことが条件となっている，一方，変位計 としての利用については, Cookらの報告"2)があり, ま た既に変位計として市販されているもの3)もあるが, その分解能は高いものでも数十 $\mathrm{nm}$ 程度である.

筆者らは被測定面と参照面からの反射光量を別々に 検出し，それらを差動増幅することによって SN 比を 高め, サブナノメータの分解能と $30 \mu \mathrm{m}$ 程度の測定範 囲を持つ高感度非接触変位計を開発したので報告す る。 


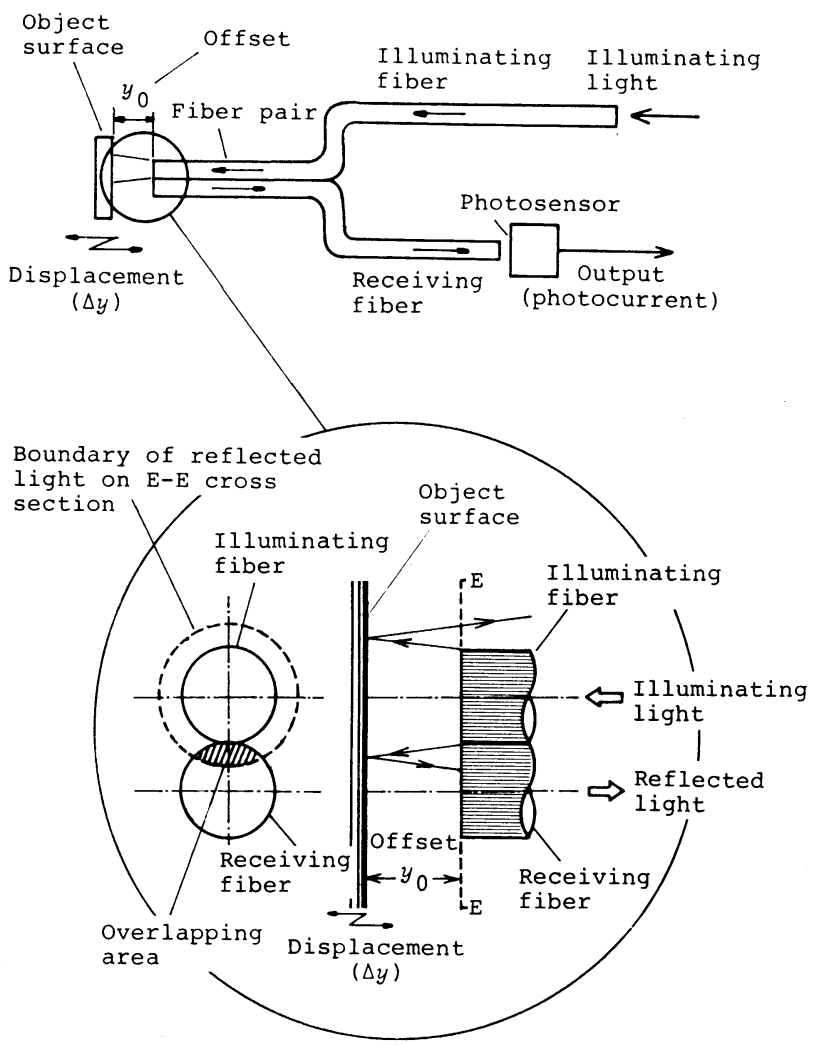

Fig. 1 Principle of reflective photo-electronic displacement sensor

\section{2. 光反射強度変化を利用した非接触変位計 の構造}

\section{1 原 理}

図 1 は受光用ファイバに入射される 被測定面からの反射光量変化から面変 位を測定する非接触変位計の基礎原理 を示すものである.投光ファイバから， ある広がり角をもって被測定面に光が 照射されるとき，その面からの反射光 のうち実質的に受光ファイバへ入射さ れる光量は, 受光ファイバ端面とそこ に㧍ける反射光束断面が重なる部分の 面積（図中の斜線部）とその部分の反 射光照度との積に比例する.このため, 一般にファイバ端面と反射面の間の距 離と受光ファイバへ入射される光量と の関係は図 2 に示すようになり, 変位 に対する光量の変化率が高い(1) の領 域を用いれば徽小な変位を高感度で検 出しうる可能性がある2)3).

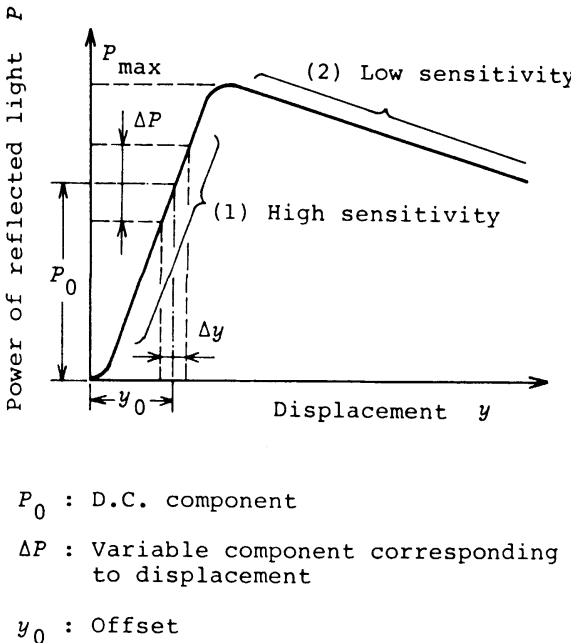

Fig. 2 Relation between power of reflected light and displacement

しかしここの基本構成のみではセンサに入 る光量が少なく，かつ変位に無関係な直流成 分によって信号の増幅率が制限されてしま い，微小変位成分を高感度に娭出することは 極めて困難である。このため，光ファイバを 多数束ねた光ファイバ束を用いて光量を増大 させて SN 比を向上させるとともに，直流成 分を除いて反射面変位に対する純粋な信号成 分のみを増幅することが必要である。

\section{2 試作変位計の構成}

図 3 に筆者らの試作した高感度非接触変位計の構成 を示す。同一光源より投光用光ファイバ束を介して被

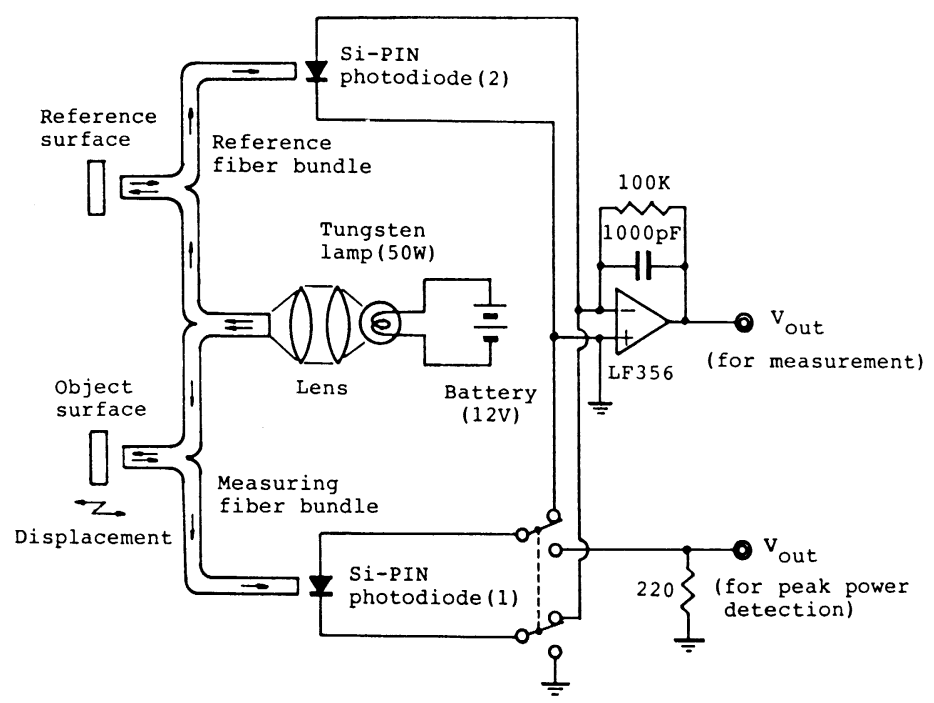

Fig. 3 Scheme of reflected photo-electronic displacement sensor with subnanometer resolution 


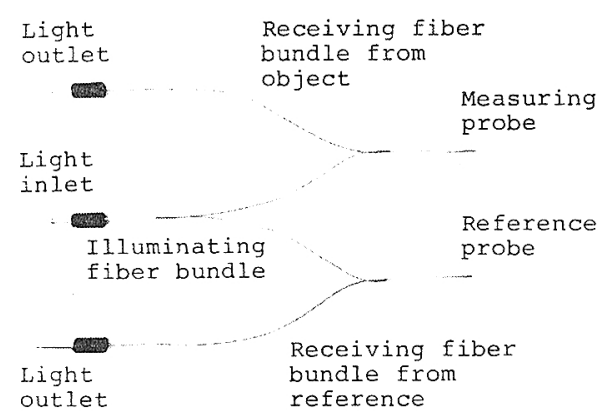

Fig. 4 A set of optical fiber bundles

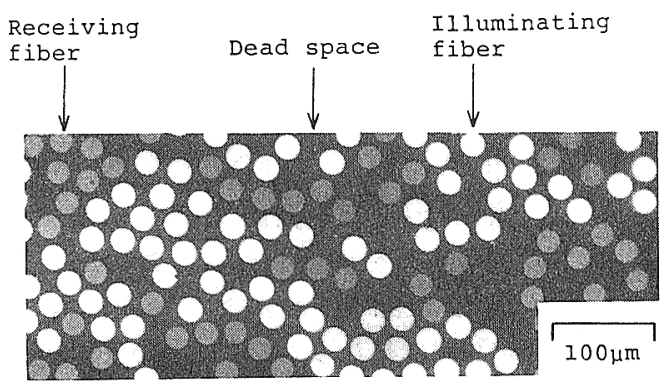

Fig. 5 A cross section of optical fiber bundle

測定面および堅固に固定された参照面に光を照射し， そ机ぞれの面からの反射光受光用ファイバ束を通じ て、別々のほぼ同等の特性を持つつォトダイオード(浜 松フォトニクス, S 1336-5 BQ) に導く。差動増幅回路 を用いて，測定用のフォトダイオード(1) と参照用の フォトダイオード（2）からの出力を差し引けば，図 2 に示した直流成分 $P_{0}$ は相殺され，败小变位に対する 信号成分 $\Delta P$ のみを増幅することができ, 高感度な変 位測定が可能となる。ここで用いられている光つァイ バ束は直径 $25 \mu \mathrm{m}$ の光ファイ :゙を, 投光用之受光用に それぞれ1200本ずつランダムに束叔た（直佳約 2 $\mathrm{mm}$ ) 測定用之参照用の 2 本のファイバ束をさらに 1 本化したもので，同一光源からの光を，それぞれの面 に同時に照射できる構造となっている。このため光源 の光量変動による感度変化は著しく軽減され，また， 被測定面上参照面を近い位置に置くことで振動や温度 等外部環境の变化に対しても鈍感であるという特徵を 持つ。このファイバ束の外観を図 4 に，またその断面 の一部を図 5 に示す.

変位の測定にあたっては，測定用プローブを図 2 に 扒ける測定可能な高感度值線領域に㧍ける適当な位置 $y_{0}$ (通常はピーク光量 $P_{\max }$ の $1 / 2$ を与之る位置) に セットし，さらにその時の差動出力がぜ口となるよう に参照面と参照用プローブとの距離を調整しておけ ば, 以後変位計からは被測定面の初期位置からの变位

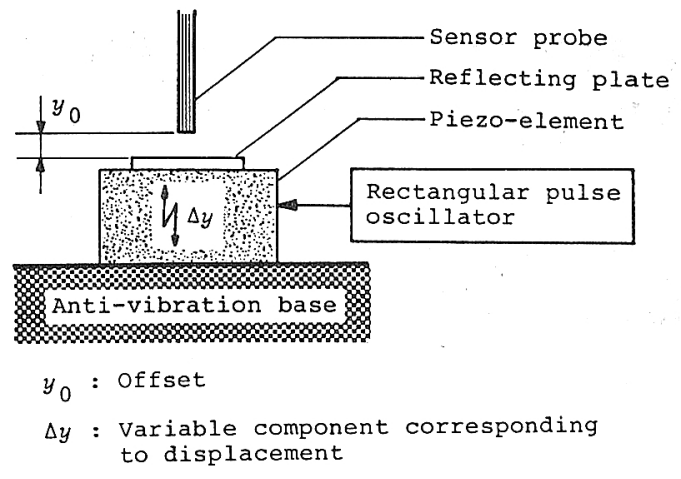

Fig. 6 Sensitivity calibration of the sensor by piezoelement

のみに対応した出力電圧が得られることになる.

な拉，商用電源を用いた場合には，信号中に商用周 波数の脈動分が含ま机, SN 比を低下させるので, 光源 および電子回路用電源にはすべて電池を使用し，なた タングステンランプからの発熱に基づく各部の熱変形 を抑制するため, ランプ抢よびレンズ系を鉄製ケース で覆い，これを水冷している。

\section{3. 試作变位計の性能}

\section{1 感度}

感度の検定は図 6 に示すように, 鏡面仕上したシり コン板にアルミニウムを蒸着したものを被測定面と し，方形波状に伸縮するピエゾ素子に接着して变位を 与え, この変位を上記非接触変位計で測定することに よって行った。実験に使用したピエゾ素子の実際の変 位量については, 微小段差測定器 (タリステップ)を 用いて校正した。図 7 (a) は $15 \mathrm{~Hz}, 0.5 \mathrm{~nm}$ の面変位 に対応する本变位計からの出力波形である。ここで $\mathrm{SN}$ 比が 1 となる状態をもって分解能を定義すれば, 本变位計は数百 $\mathrm{Hz}$ 以上の高い周波数領域に捛いても $0.5 \mathrm{~nm}$ 程度の分解能を持っているものと判断できる。 图 7 (b) は, $1 \mathrm{~Hz}, 0.5 \mathrm{~nm}$ の变位に対する变位計出力 を10 Hzのローパスフィルタを通して観測したもの で，低い周波数領域に限定すれば，さらに分解能は向 上することがわかる。なお図 7(a)に見られるノイズ は，フォトダイオード，電子回路拉上び検定を行った 防振台の防振特性等に起因するものと考完られるが， それぞれの大きさの程度は今のところ明らかではな い.

また，本変位計を使用する際，プローブが被測定面 に対して直角にセットさていない場合が考兄られる が，土3゚以内の傾きであれば測定上全く問題ないこ とを実験的に確認した。 

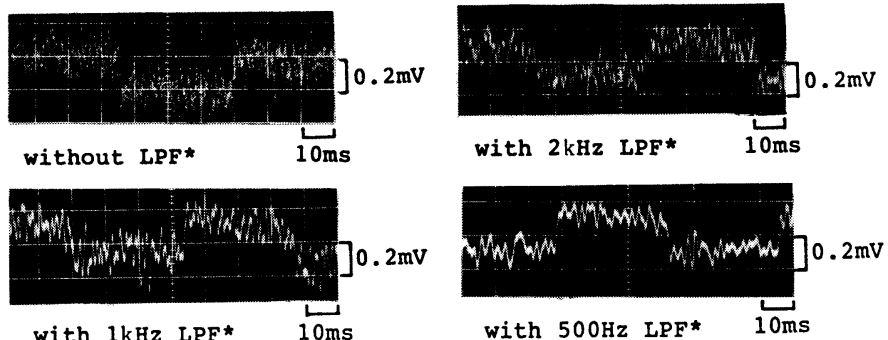

(a) Outputs corresponding to $15 \mathrm{~Hz}, 0.5 \mathrm{~nm}$ rectangular displacement at various cut-off frequency

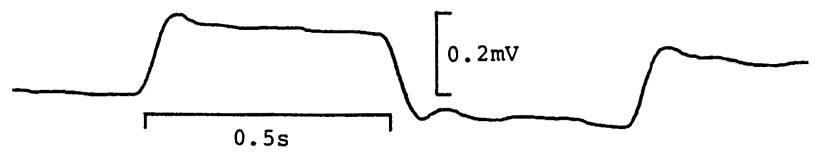

(b) Output corresponding to $1 \mathrm{~Hz}, 0.5 \mathrm{~nm}$ rectangular displacement (with $10 \mathrm{~Hz}$ LPF*)

Fig. 7 Resolution of the sensor ( ${ }^{*} \mathrm{LPF}$; low pass filter)

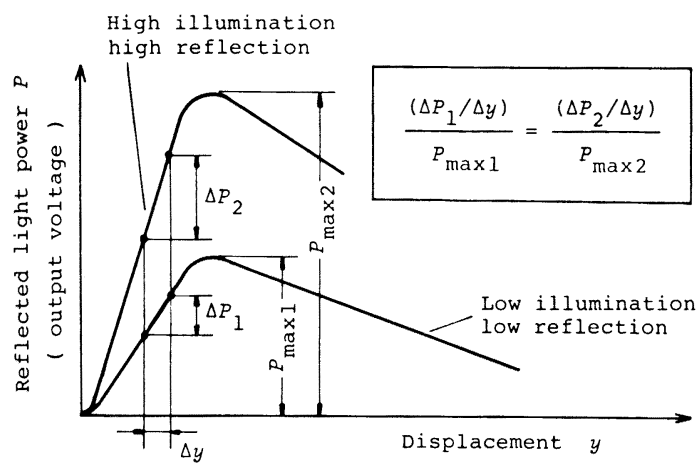

Fig. 8 Invariability of sensitivity to the surfaces with different reflections

ところで，本変位計における出力電圧は，被測定面 の变位以外に照射光量および被測定面の反射率によっ ても変わるが，図８に示すように被測定面の単位変位 に対する反射光量の変化率 $\alpha$ は, 特にピーク光量 $P_{\text {max }}$ の $1 / 2$ の光量を与光る位置付近においては, $P_{\max }$ の大 きさに比例するため, それらの比 $k=\alpha / P_{\max }$ は被測定 面によって $P_{\max }$ が変化しても一定である.このため測 定に先立って反射ピーク光量 $P_{\text {max }}$ を求めて拈き，プ ローブ先端の位置を $P_{\max } / 2$ を与光る位置にセットし て打けば，検出される反射光量の变化 $\Delta P$ から被測定 面の変位 $\Delta y$ は $\Delta y=\Delta P /\left(k P_{\max }\right)$ によって求めるこ とができる.

試作した光ファイバ束に関して, 種々の精密加工面 を用いて実験したところ，1\%以内の精度で上記の関 係が満足されていることを確認した。なお $P_{\max } / 2$ を与
党るプローブ先端の位置は, 通常の精密 加工面に扮いては面から 20 30 $\mu \mathrm{m}$ 程 度離れた位置にあたる。

\section{2 直 線 性}

図6に示した方法および図 9 に示すよ らな, 片持ちはりに荷重を加えた時に生 ずる弾性変形に基づく被測定面の微小変 位を利用して, 約 $3 \mu \mathrm{m}$ の微小な測定範 囲における直線性を調べた結果が図 10 である。この範囲では誤差 $1 \%$ 以下の非 常に良好な特性をるつことが明らかに なった。ささら，図11 に示すよらに測定 用プローブの先端位置を平行板ば㸚を利 用して変位させ，その時の変位量と測定 用プローブへの反射光量 (反射ピーク光 量に対する反射光量の比）との関係を約 $30 \mu \mathrm{m}$ の範囲にわたって調べた結果が

図12である。これより本变位計は 30 $\mu \mathrm{m}$ 程度の測定範囲にわたって $5 \%$ 以内の直線性を示 すことが明らかになった。

\section{3 安定性（ドリフト）}

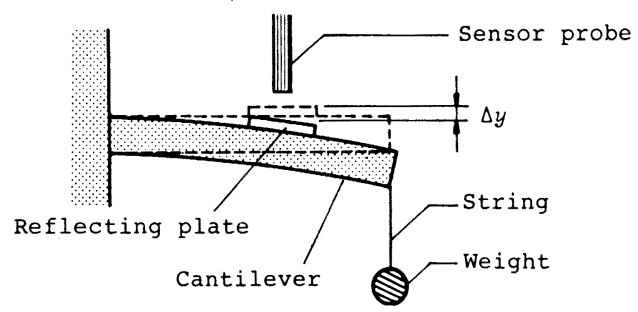

Fig. 9 Sensitivity calibration of the sensor by small elastic deflection of cantilever

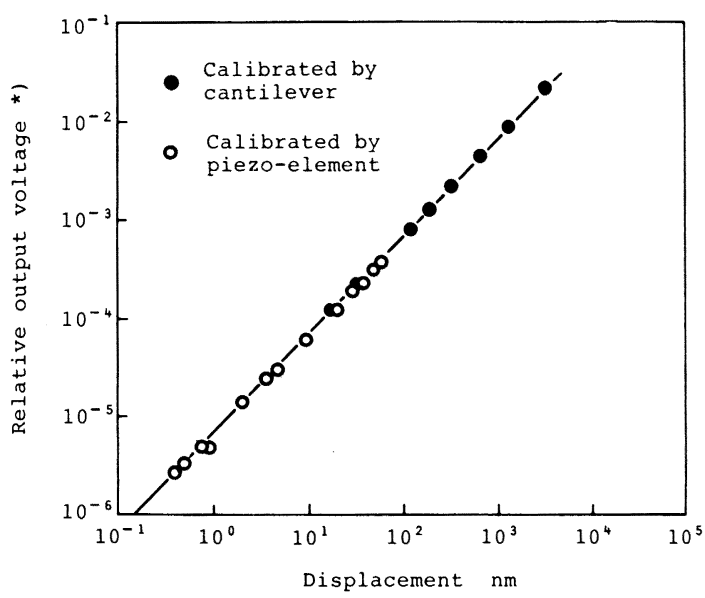

Fig. 10 Short range linearity of the sensor (*elative value to that of maximum reflection) 


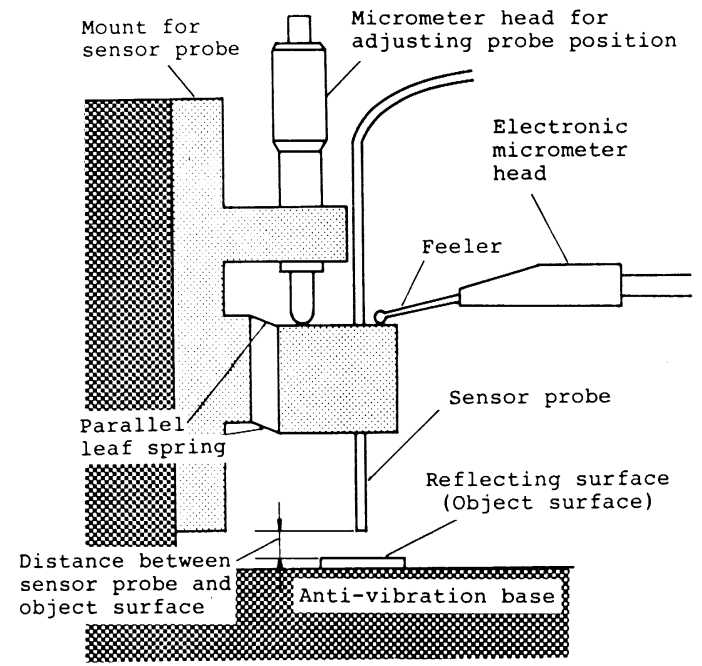

Fig. 11 Calibration setup for large displacement

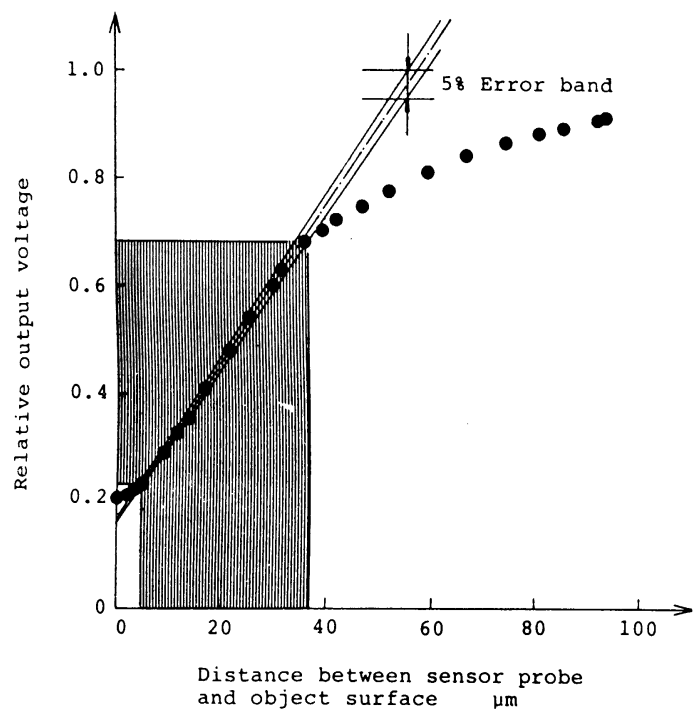

Fig. 12 Working range of the sensor

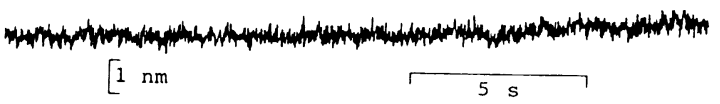

Fig. 13 Drift of the sensor

図 13 は被測定面と参照面を防振台上に堅固に固定 された同一の固定体に取り付け，両面を無变位の状態 にしておき，その時の出力信号を観測したもので，20 $\mathrm{s}$ 間にわたり $1 \mathrm{~nm}$ 以内の精度で安定であることがわ かる.このドリフトは主としてタングステンランプの 発熱による各部の熱変形が原因と考えられるが, 詳細 については今のところ明らかではない。

なお本変位計による測定においては，プローブ先端 と被測定面の間隔は通常数十 $\mu \mathrm{m}$ であるため, 測定値 に対する空気流動等の影響はほとんど問題とならず, また周囲の温度変化に対しては，年間の使用を通じて その感度に変化が見られないことが実験的に確かめら れており, 本変位計は通常の環境下においては非常に 対環境性に優れた特性を持っていると考えられる。

\section{4. 結}

同一光源からの光を分岐した 2 本の投光ファイバ束 を通して，変位する被測定面と堅固に固定された参照 面へ照射して, 受光ファイバ束へ戻るそれらの面から の反射光量を別々のフォトダイオードによって検出 し, 両者の差動増幅を行うことで, 構造は極めて簡単 であるにもかかわらず，サブナノメータの分解能と 30 $\mu \mathrm{m}$ 程度の測定範囲および $1 \mathrm{~nm} / 20 \mathrm{~s}$ の安定性を持っ た高感度非接触変位計を開発することができた。これ は, その特性から見て, 例えば軸の回転精度や機素の 運動精度などの短時間（例えば $1 \mathrm{~min}$ 以内）の超高精 度測定に対して極めて有用であると考えられる。

\section{謝辞}

本研究の遂行にあたっては, 昭和 58 年度高度生産シ ステム振興財団の研究助成を頂いた。 また光ファイバ 束の製作について多大のご協力を賜ったオリンパス光 学工業(株) 研究開発本部, 洲脇利孝氏, 佐藤千秋氏, 実験にご協力を頂いた松原正二氏，平野均氏に深甚の 謝意を表する次第である。

\section{参 考 文 献}

1）斉藤勝政, 三好隆志：ファイバオプティクス光沢計の原理 一ファイバオプティクスによる金属鏡面の光沢測定に 関寸る研究 (第 1 報)，精密機械，40，2（1974） 129 .

2) R. O. Cook and C. W. Hamm: Fiber Optic Lever Displacement Transducer, Appl. Opt., 18, 19, (1979) 3230.

3）例えば, EDDIO Corporation, EDDIOPT-MS カタログ. 